


\section{Identification, cataloguing and preservation of outcrops of geological interest in monogenetic volcanic fields: the case of La Garrotxa Volcanic Zone Natural Park}

Llorenç Planagumà, 1,2

Joan Martí, 3四

Email joan.marti@ictja.csic.es

1 Tosca, Environment Services, 17800 Olot, Spain

2 Departament de Geografia, Institut de Medi Ambient, Facultat de Lletres, Universitat de Girona, 17071 Girona, Spain

3 Geosciences Barcelona, CSIC, 08028 Barcelona, Spain former Institute of Earth Sciences Jaume Almera

Received: 19 May 2020 / Accepted: 16 September 2020

\section{Abstract}

Volcanic zones are important geoheritage sites. Active volcanic fields are of special interest because they allow to observe the complex and interesting stratigraphic relationships that often characterise their products and processes, as well as landscapes of unusual beauty. These geological sites enable visitors to appreciate the full complexity of volcanic activity and the importance of the geoheritage values that should be preserved. To ensure a correct preservation of these zones while opening them up to visitors, management plans should establish and consolidate a network of outcrops that allow visitors to get to know the area in question and preserve its geological heritage and the social and economic dynamism. In La Garrotxa Volcanic Field, most of which is protected by a natural park, a new methodology has been created to 
identify the sites of greatest geological interest and, above all, those that exemplify the diversity of eruptive styles and volcanic products and landforms in the area. Taking into account the most relevant management requirements (conservation and dissemination), in 1994 a total of 60 outcrops were classified as points of geological interest of the area. In this study we further present a specific methodology to select the most suitable sites for the preservation of the main volcanological features of La Garrotxa Volcanic Field. A group of 12 sites were selected from the initially identified outcrops and included in an itinerary as the most representative geological and pedagogical sites while also bearing in mind their ease of access and preservation and the possible impact of visitors (e.g. erosion). The following five criteria were considered when restoring these outcrops: integration into the landscape, consolidation of their geology, regulation of visits, the mitigation of risk, and the participation of the people that live in the area.

\section{Keywords}

Catalan volcanic zone

Geological heritage

Monogenetic volcanism

Spain

Outcrops

Geosites

\section{Introduction}

Geoheritage and geoconservation are important global endeavours designed to preserve Earth Science features recognised by various international and international conservation bodies and enshrined in numerous agreements, conventions and inter-governmental initiatives (Brocx and Semeniuk 2007). Geodiversity embraces all of the geological aspects identified on Earth and as such is a measure of the geological diversity of a particular area; geoheritage, on the other hand, is defined as those parts of geodiversity that are important for reconstructing the history of our planet (Sharples 1993; Gray 2019) and thus is a measure of the value of the geological elements that are present therein (Gray 2013, 2019).

Geodiversity and geoheritage benefit society, as they provide evidence of 
our understanding of the history of the Earth and are a convincing reason for the conservation of geological values (Gray 2019).

Geoconservation includes the protection of geoheritage features and geosites and, more generally, the application of geoconservation principles in the sustainable management of protected areas and the wider landscape (Gordon et al. 2018). In this sense, geoconservation involves the protection of those elements of geodiversity that are of high geoheritage value, mainly for scientific reasons but also for their educational, cultural, aesthetic, spiritual and ecological content (Crofts and Gordon 2015; Gray 2013; Gordon et al. 2018). Therefore, the success of the conservation of the geodiversity of an area will depend on how well we protect its natural geological heritage (Németh et al. 2017); thus, geosite selection and conservation management and monitoring are critical aspects of geoconservation strategies at all levels (Carcavilla et al. 2008; Gordon et al. 2018).

The study and appreciation of the geodiversity of an area are essential elements in the identification and protection of the geological values that best represent its geological heritage. First, it is crucial to undertake a geodiversity assessment based on a selection of criteria dependent on factors such as the purpose of the assessment, the type of landscape in the study area and its spatial dimension, the significance of the different geological values to be preserved, and the availability of spatial data at an appropriate scale (Brocx and Semeniuk 2007; Zwolinski et al. 2018). Once this assessment has been conducted, the next step is to identify the elements that reflect the geological value of the area and contribute most to explaining its geological history. Finally, it is necessary to decide which management and preservation policies from various perspectives-i.e. based on geotouristic, geoconservation and geoeducation values - are of greatest importance (Németh et al. 2017).

Numerous examples exist of geodiversity preservation and of how it can be based on the specific characteristics of an area, the geological values to be protected and current political and administrative regulations (e.g. Burek and Colin 2008, and references therein; Brilha 2016, 2018). The result of all these efforts to preserve these geological values is reflected in the UNESCO geoparks, the national and natural parks that protect geological features and many other protected geosites that exist worldwide. The 
protection and preservation of geological values should not mean that they are inaccessible to the general public. On the contrary, protected geological sites, whenever possible, should be visitable, provided that their conservation is guaranteed and visitors are furnished with correct information about their relevance and their local value. Therefore, geoheritage protection also means drawing up the best possible management and conservation protocols for the identification, access and dissemination of all points of observation that define a particular protected area (Planagumà and Martí 2018).

AQ1

Volcanic zones are home to complex and interesting stratigraphic relationships (Cas and Wright 1988) and are often endowed with immensely important geoheritages. Active volcanic fields are of special interest since they tend to boast rich soils and accessible sites of exceptional geological interest and beautiful landscapes, along with active volcanic features (Németh et al. 2017; Casadevall et al. 2019). In fact, active volcanic zones have become increasingly attractive to geotourists, who seek both live and extinct volcanic landscapes, as well as adventure and enjoyment. Therefore, as occurs in other protected geozones, the creation of a network of outcrops is a key step in the preservation of local geological heritage and the protection of related social and economic dynamics in these protected volcanic zones.

In this study we discuss how the protection of a volcanic heritage zone has been carried out in La Garrotxa Volcanic Field (Martí et al. 2011), a large part of which lies within the boundaries of a natural park (La Garrotxa Volcanic Zone Natural Park, PNZVG) that annually receives around 350,000 visitors. In order to identify and define a network of visitable outcrops that could best represent the main geological and volcanological values of the area (Table 1, Fig. 1), a specific methodology was developed with objective to incorporate the whole diversity of eruptive styles, products and landforms present in the area. Thus, in order to identify the most representative features, within this area of $200 \mathrm{~km}^{2}$, in terms of their relevance and potential dissemination, a hierarchical selection of outcrops of geological interest was carried out; it also took into account access, future management and preservation criteria and the need to minimize risks for visitors. Here we describe how this methodology was developed and 
applied and analyse the results of its implementation in this area over the past 30 years.

Table 1

Different types of volcanic deposits in La Garrotxa Volcanic Zone Natural Park.

\begin{tabular}{|c|c|c|c|c|}
\hline & & \multicolumn{2}{|r|}{ Volcanic deposit } & Examples of \\
\hline \multirow{3}{*}{ Effusive } & & 1 & $\begin{array}{l}\text { Lava flow with } \\
\text { basalt columns }\end{array}$ & $\begin{array}{l}\text { Castellfollit de la } \\
\text { Roca, El Boscarró } \\
\text { (Sant Joan les } \\
\text { Fonts) }\end{array}$ \\
\hline & & 2 & $\begin{array}{l}\text { Lava flow with } \\
\text { rootless volcanic } \\
\text { cones }\end{array}$ & $\begin{array}{l}\text { Bosc de Tosca, Pla } \\
\text { de Dalt }\end{array}$ \\
\hline & & 3 & $\begin{array}{l}\text { Lava flow with } \\
\text { lenticular } \\
\text { formations and } \\
\text { blisters }\end{array}$ & $\begin{array}{l}\text { Molí Fondo (Sant } \\
\text { Joan les Fonts) }\end{array}$ \\
\hline \multirow{7}{*}{ Explosive } & \multirow{3}{*}{ Strombolian } & 4 & $\begin{array}{l}\text { Welded pyroclasts } \\
\text { in rootless volcanic } \\
\text { cones }\end{array}$ & $\begin{array}{l}\text { Parc de Pedra } \\
\text { Tosca, Pla de Dalt. }\end{array}$ \\
\hline & & 5 & $\begin{array}{l}\text { Pyroclasts in } \\
\text { spatter cones }\end{array}$ & La Pomareda \\
\hline & & 6 & $\begin{array}{l}\text { Pyroclasts (blocks, } \\
\text { lapilli and bombs) } \\
\text { in Strombolian fall } \\
\text { deposits }\end{array}$ & $\begin{array}{l}\text { Former quarries on } \\
\text { volcanoes of } \\
\text { Rocanegra and Puig } \\
\text { Jordà }\end{array}$ \\
\hline & \multirow{2}{*}{$\begin{array}{l}\text { Violent } \\
\text { Strombolian }\end{array}$} & 7 & $\begin{array}{l}\text { Pyroclasts (blocks, } \\
\text { lapilli and bombs) } \\
\text { in violent } \\
\text { Strombolian fall } \\
\text { deposits }\end{array}$ & $\begin{array}{l}\text { Former quarries on } \\
\text { El Croscat. }\end{array}$ \\
\hline & & 8 & $\begin{array}{l}\text { Pyroclast layers in } \\
\text { violent } \\
\text { Strombolian fall } \\
\text { deposits }\end{array}$ & $\begin{array}{l}\text { Outcrop along } \\
\text { Torrent de Can } \\
\text { Bosquet }\end{array}$ \\
\hline & \multirow{2}{*}{ Phreatomagmatic } & 9 & $\begin{array}{l}\text { Pyroclastic flows } \\
\text { with Eocene lithics }\end{array}$ & $\begin{array}{l}\text { Former quarry on } \\
\text { Can Tià, along track } \\
\text { to Mas El Cros in } \\
\text { Santa Margarida. }\end{array}$ \\
\hline & & 10 & Explosive breccia & $\begin{array}{l}\text { Former quarry of } \\
\text { Can Barranc del } \\
\text { Cairat }\end{array}$ \\
\hline
\end{tabular}




\begin{tabular}{|c|c|c|}
\hline & Volcanic deposit & $\begin{array}{c}\text { Examples of } \\
\text { outcrops }\end{array}$ \\
\hline 11 & $\begin{array}{l}\text { Pyroclastic flows } \\
\text { with volcanic } \\
\text { lithics }\end{array}$ & $\begin{array}{l}\text { Former quarry on } \\
\text { south flank of El } \\
\text { Montsacopa; former } \\
\text { quarry on El } \\
\text { Croscat. }\end{array}$ \\
\hline 12 & $\begin{array}{l}\text { Basaltic } \\
\text { ignimbrites }\end{array}$ & $\begin{array}{l}\text { El Carrer, Can } \\
\text { Bufador de la } \\
\text { Garrinada }\end{array}$ \\
\hline
\end{tabular}

\section{Fig. 1}

Aerial photograph of the northern side of La Garrotxa Volcanic field

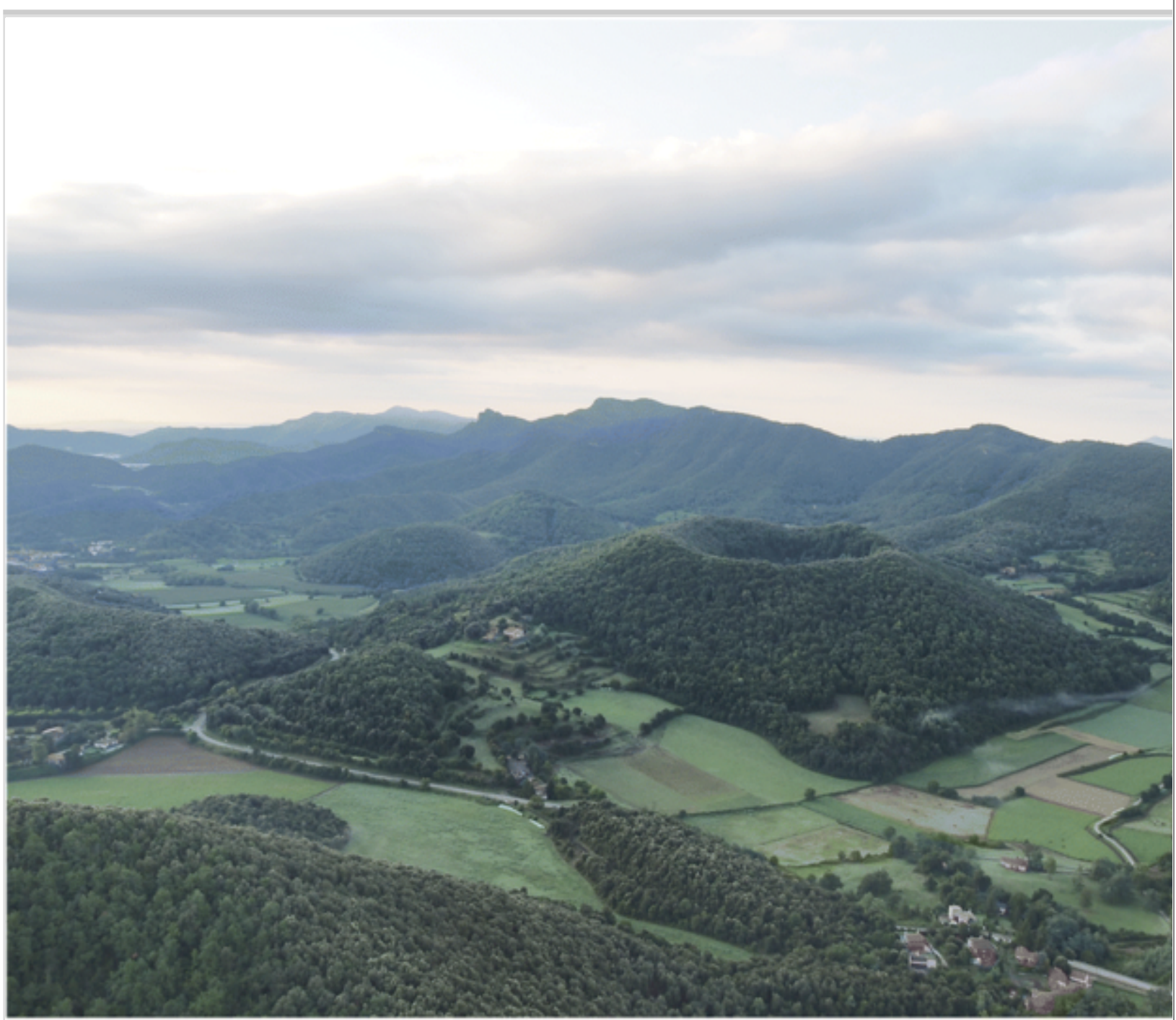

\section{Geological setting}

La Garrotxa Volcanic Field (LGVF) (Fig. 1) lies in the north-east Iberian 
Peninsula (Fig. 2) and forms part of the Neogene-Quaternary Catalan Volcanic Field, which is associated with the European Rift that extends from the Alboran Sea to the centre of the continent (Lewis et al. 2000; Martí et al. 1992). This rift began to form as a result of the distension initiated $20 \mathrm{Ma}$ during the Neogene when the Alpine orogeny affecting southern Europe came to a halt. The volcanism associated with this rift is alkaline in type and has given rise to a number of volcanic zones, of which LGVF $\left(200 \mathrm{~km}^{2}\right)$, lying between the cities of Girona and Olot, is the most recent. This volcanic field (Fig. 3) contains around 50 cinder cones (Bolós et al. 2014), as well as numerous lava flows, tuff rings and maars dating from the Middle Pleistocene (0.12-0.78 Ma) to the beginning of the Holocene (0.01 Ma) (Bolós et al. 2014). These volcanic features lie atop Eocene sedimentary rocks and Quaternary alluvial deposits, as well as a series of Paleozoic granites and schists (Losantos et al. 2000). The magma generated in this volcanic field is basaltic, basanite, nepheline basanite and olivine basalt; in many cases the magma is the primary source and is not differentiated or contaminated by materials from the Earth's crust (Cebría et al. 2000).

\section{Fig. 2}

Map of the European rift, the main volcanic zones and protected volcanic areas 


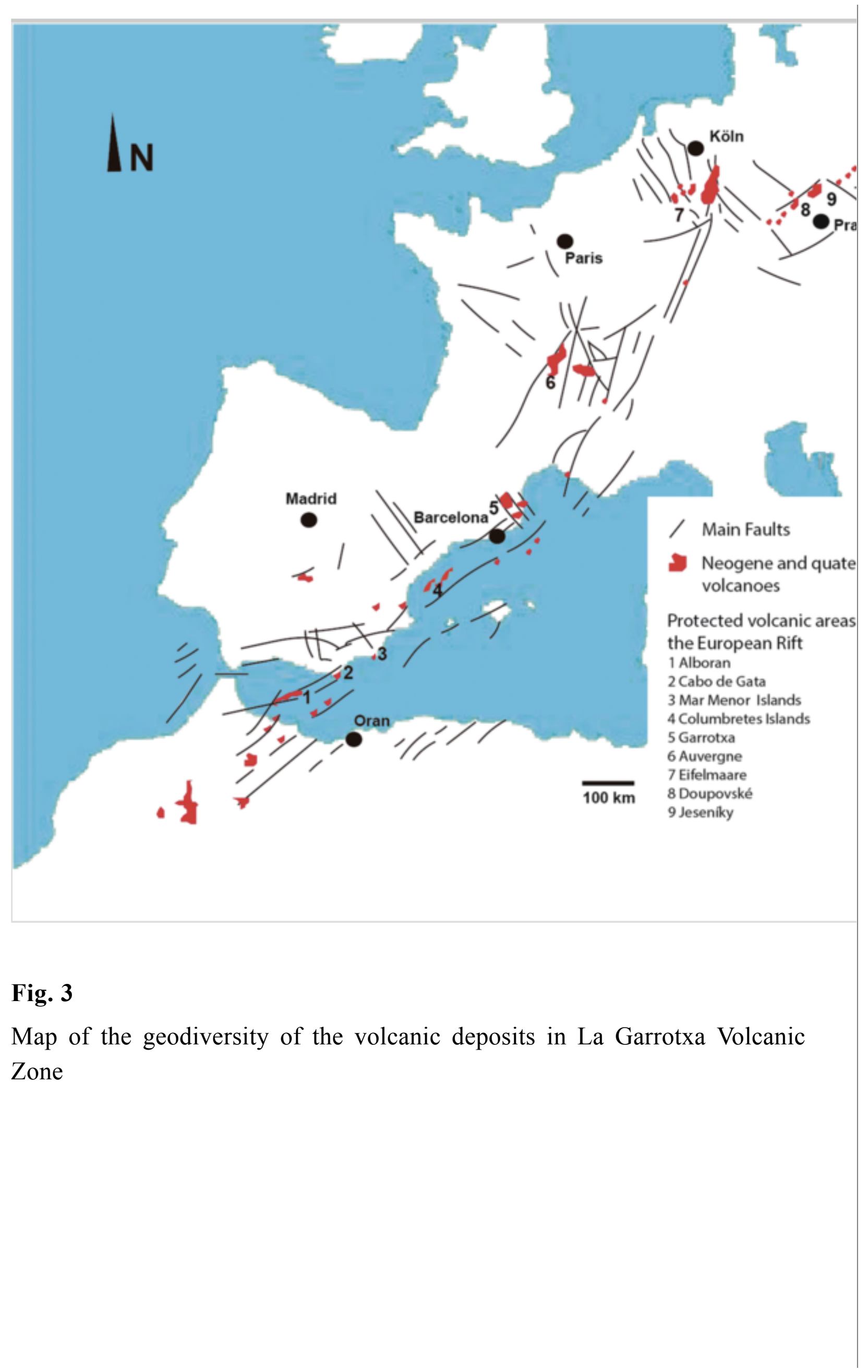




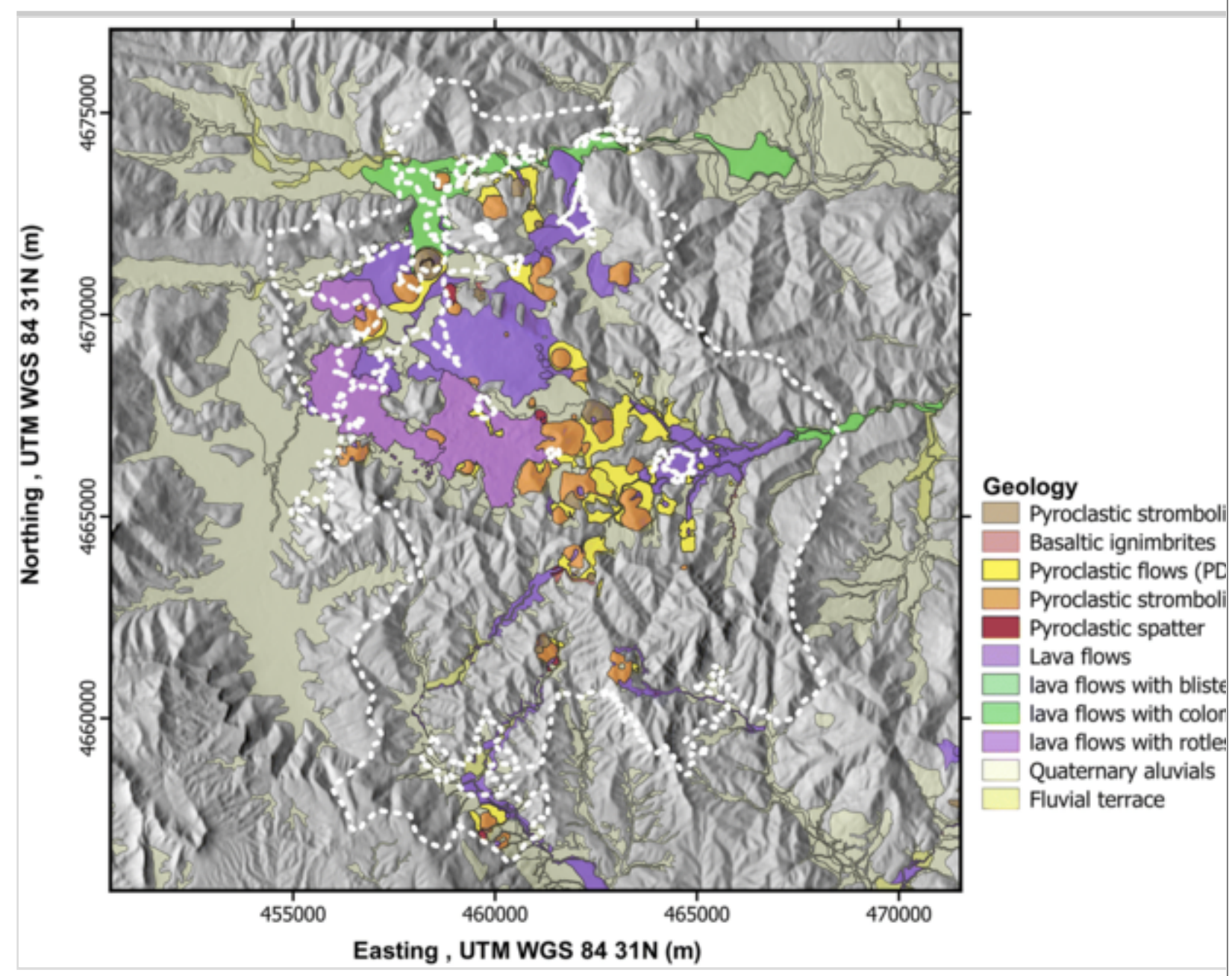

Most of the volcanoes in LGVF lie around the city of Olot and the village of Santa Pau, or, as in the case of the volcanoes of La Crosa de Sant Dalmai, Canet d'Adri and Puig de Granollers, a few kilometres south of the latter locality (Bolós et al. 2014). These small monogenetic cones arose as a result of a succession of different pulsations of magma that rose to the surface through a series of secondary NW-SE running faults associated with the major Llorà and Amer faults, active since the Miocene (20 Ma) (Martí et al. 1992), that generated fissural activity. The volume of these magmatic pulsations was moderate $\left(0.01-0.2 \mathrm{~km}^{3}\right)$ (Bolós et al. 2014), and the resulting lava was emplaced in spatter and scoria cones, lava flows, maars and tuff rings. Due to the varied lithology of the substrata and the variety of hydrogeological features it has generated, the volcanic cones display a great variety of sequences and types of volcanic deposits (Martí et al. 2011). For instance, in the volcano of Crosa de Sant Dalmai, the magma interacted with the Quaternary alluvial aquifer, while in the volcano of Can Tià interaction occurred with the Eocene sedimentary aquifer. 
The main type of volcanic activity in this area was Strombolian and gave rise to scoria cones composed of a series of fall deposits (lapilli and blocks). Many of these monogenetic cones (e.g. the volcanoes of Rocanegra, Montolivet, Sant Marc and L'Estany) are characterised by the presence of horseshoe-shaped cones. In some cases, however, where magma and groundwater from shallow aquifers interacted the eruptions were more complex and were characterised by phreatomagmatic phases involving phreatic explosions with ejection of lithic fragments from the substrate, as well as different types of pyroclastic density currents and phreatomagmatic fallout (Martí et al. 2011). Examples of this type of volcanic activity include the volcanoes of Santa Margarida, Croscat, Garrinada, Crosa de Sant Dalmai, Canet d'Adri and Can Tià (Martí et al. 2011). As a whole, Strombolian and phreatomagmatic activity have created a complex variety of eruptive sequences and volcanic morphologies that include cinder cones, maars, lava flows, rootless cones and lava tubes.

The inspection of the lithic fragments found in the phreatomagmatic deposits has permitted to identify the existence of three main aquifers that interacted with basaltic magma during the construction of LGVF (Martí et al. 2011). One aquifer lies at around 300-100 $\mathrm{m}$ and another much nearer the surface, just a few dozen metres below ground level. The deeper of the two lies in Eocene detritic sedimentary rocks (Bellmunt Formation), which consist of continental sediments composed of conglomerates, mudstones rich in feldspars and red lutites; the more superficial aquifer lies within alternating beds of volcanic and Quaternary alluvial deposits composed largely of unconsolidated sands, clays and volcanic rocks (lavas and pyroclasts) dating from previous eruptions. Finally, there is a third aquifer that also played an important part in some of the most explosive eruptions in LGVF (Puig de Banya del Boc and Crosa de Sant Dalmai), which lies within highly fractured Paleozoic rocks at depths varying from a few hundred metres to just a few metres, depending on the tectonics of each particular area (Bolós et al. 2012; Pedrazzi et al. 2014).

Therefore, the volcanoes of the La Garrotxa reveal how complex a small volcanic field can be when magma interacts with groundwater, thus producing a great diversity of eruptive sequences which contrast with the relative monotony of the co-existing Strombolian volcanism. This complexity is heightened if the aquifers possess differing hydrogeological 
characteristics and the structure of the terrain is heterogeneous due to tectonic movements and/or differences in local stratigraphy (Martí et al. 2011).

\section{La Garrotxa Volcanic Zone Natural Park}

La Garrotxa Volcanic Zone Natural Park (PNZVG, in its Catalan spelling) covers an area of 15,000 ha and includes most of the northern part of La Garrotxa Volcanic Field (Fig. 3). The Park contains both public and private land, including built-up areas with 33,000 inhabitants and forty wellpreserved volcanic cones, twenty-six of which are natural reserves (Planagumà 2017). The PNZVG was declared by the Parliament of Catalonia in 1982 (Law 2/1982, March 3) to guarantee the protection of the volcanic area of La Garrotxa. It was declared as a Natural Site of National Interest to ensure that its flora, volcanic geomorphology and exceptional scenic beauty would be preserved.

Two main elements can be distinguished in the geological heritage of the PNZVG: volcanic morphologies and outcrops (Fig. 4). Their importance lies in the uniqueness of their constituent materials and the representativeness of the geological processes that allow them to be interpreted as the result of hundreds of thousands of years of geological and volcanological activity. The best-preserved volcanic cones are protected as natural reserves, while other geological outcrops are catalogued as outcrops of geological interest. The regulations governing the protection of this geological heritage are enshrined in the PNZVG's management plan (Planagumà 2017).

Fig. 4

Map of the selected outcrops 


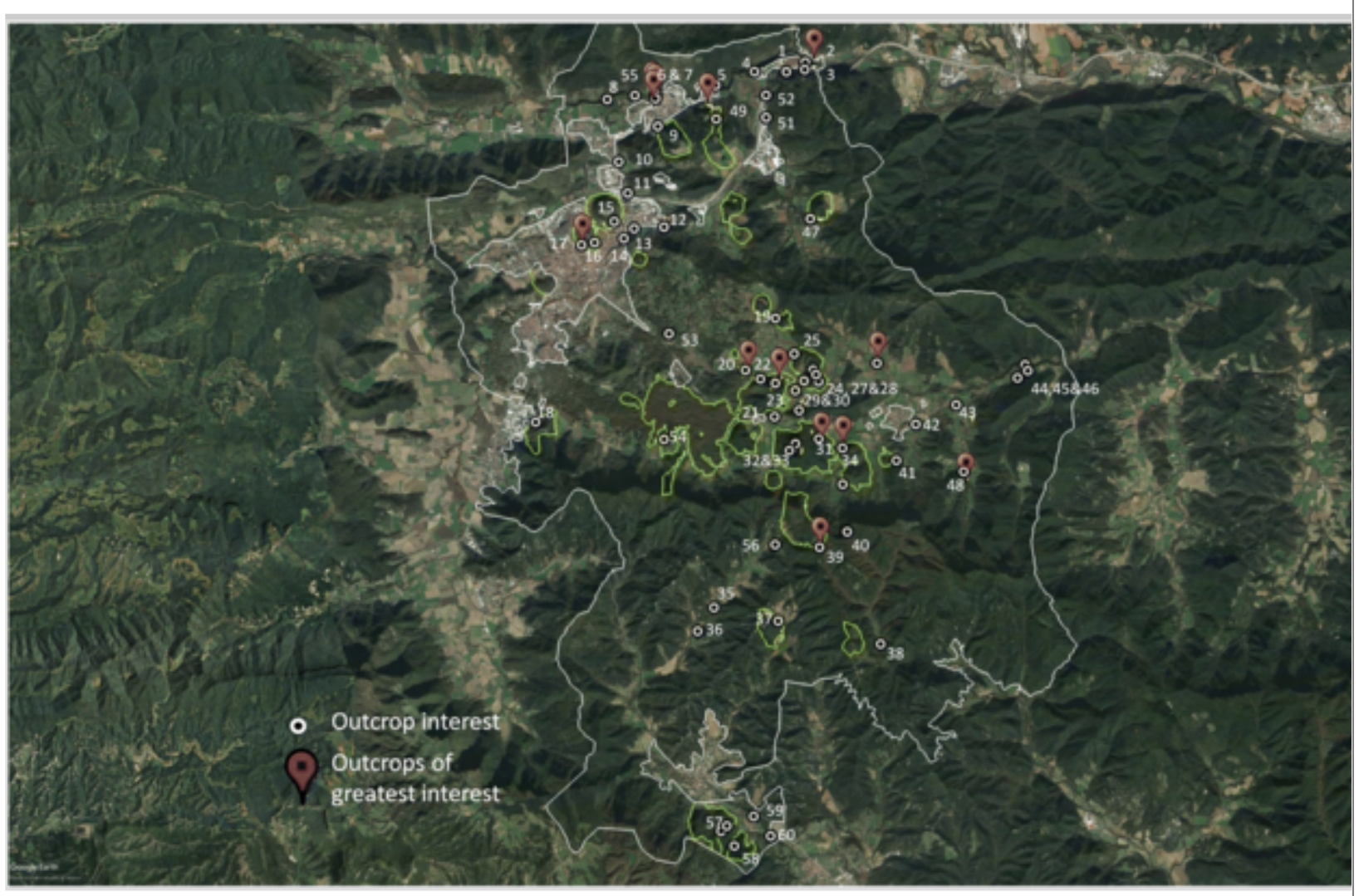

All the natural reserves (i.e. all the best-preserved volcanic cones) (Fig. 4) are natural areas that receive special protection, conservation and management to prevent any deterioration, transformation or disfiguring of their geomorphology or flora. The protection of the geological heritage of the PNZVG ensures that no activities that might provoke or accelerate erosive processes or increase the instability of the substrata may be performed and that the singular volcanic soils present in most of the area are strictly preserved. In addition, the outcrops considered of geological interest are identified and catalogued, and strict regulations govern their protection. For instance, no activity that might degrade or deteriorate the protected area or hamper its observation or study is permitted. Moreover, excavations and other types of earth movements are forbidden unless they are designed to improve or restore the volcanic outcrops for scientific or educational purposes and have been approved by the protected area's management team. The areas adjacent to these outcrops should also be kept free of any disturbance that might obstruct their observation. The PNZVG gives priority to the active management of outcrops of exceptional interest and seeks agreements and collaboration with landowners as a way of guaranteeing the maximum protection for these sites, if necessary in combination with external support. 


\section{Criteria Used to Select the Outcrops that Best Represent the Volcanic Geological Heritage of the Zone}

In addition to the rich soils and benign climate that favour the development of dense vegetation cover (Oliver 2016) and despite the burgeoning economic development of this relatively well-populated zone, the PNZVG harbours a large number of visible volcanic outcrops. The first special protection plan designed to regulate the conservation of this protected area catalogued 50 sites of geological interest (Planagumà 2017). Given that the conservation of so many sites is costly in terms of both human and economic resources, a methodology was established to select the most interesting outcrops and illustrate the great variety of types of volcanic deposits existing in the area.

Therefore, as part of the protection of this volcanological geoheritage and to facilitate public access in a sustainable manner, a selection of the most representative outcrops of the greatest geological and volcanological interest was established based on their relevance in terms of three main aspects: research, conservation and dissemination. After testing 50 selected outcrops and 10 further outcrops discovered in recent years during a study of ephemeral sites (Bolós et al. 2014) (Table 3 and Fig. 4), 12 outcrops of great geological interest were identified (Table 3 and Figs. 4, 5, and 6). The remaining outcrops were discarded as being poorly representative, poorly accessible, or irreversibly damaged or due to a combination of two or more of these reasons (Figs. 5 and 7).

\section{Fig. 5}

Graph showing the relationship between dissemination and conservation prioritizing outcrops. Red dots correspond to the outcrops; recommendations for active management are in the grey square (top and left) 


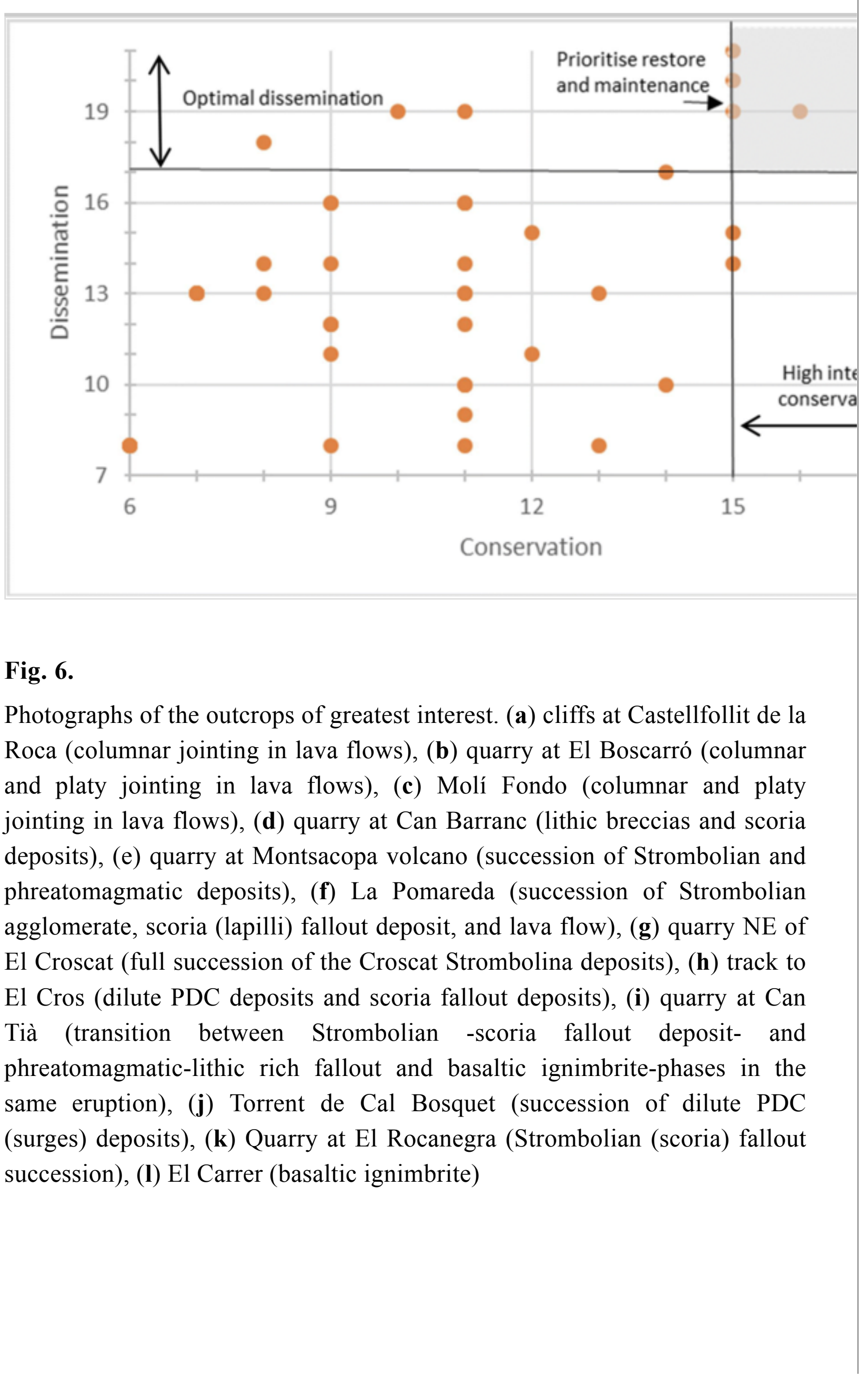



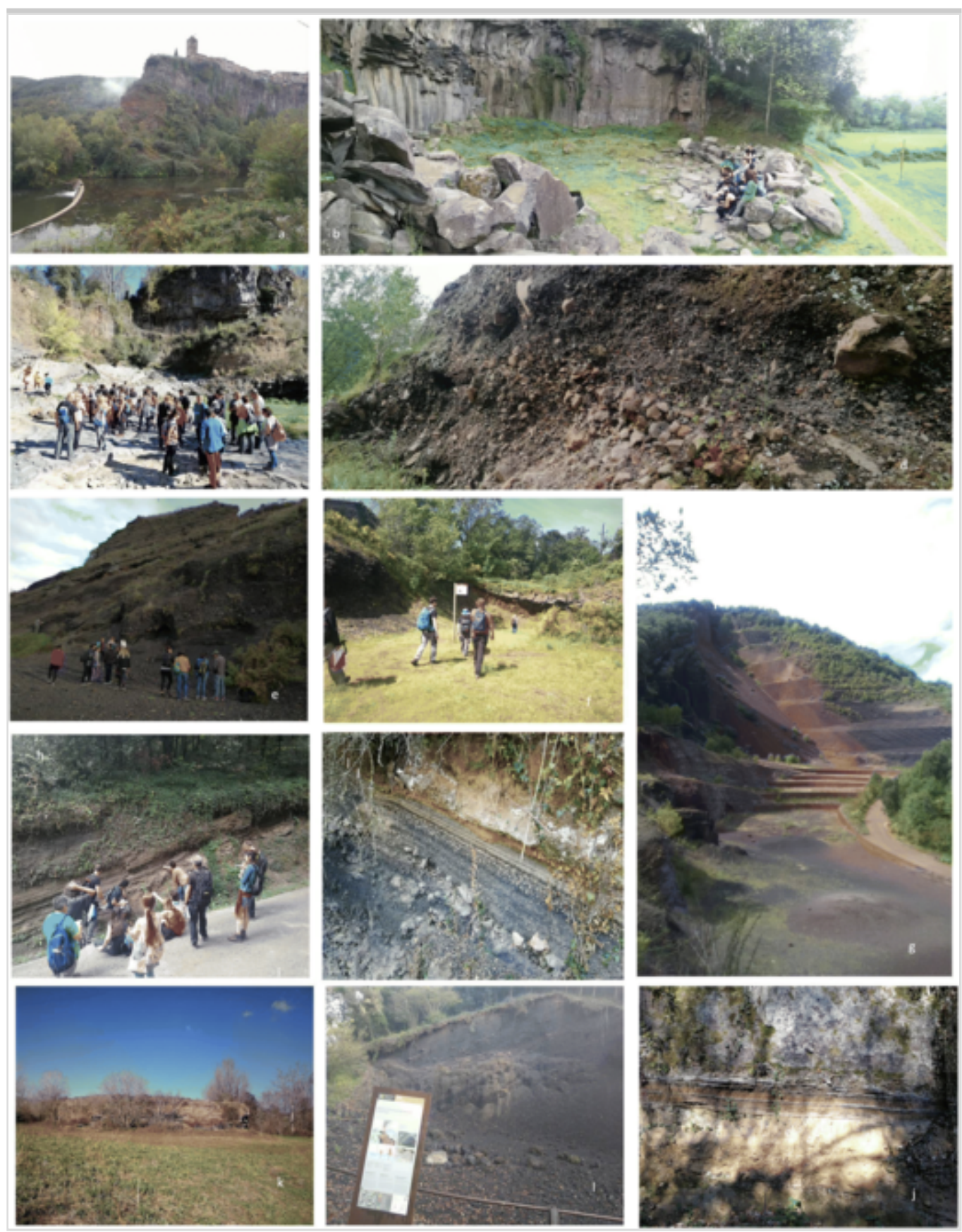

Fig. 7

Photographs of the outcrops of less interest. (1 and 2) Little use for illustrating geological processes (scoria fallout deposits) duet to extensive vegetation coverage, (3) problems with landowner, (4) poor observation (lava flows) possibilities, (5) poor state of conservation (former quarry used now as illegal dump) and (6) inaccessible or only observable from long distance (columnar jointing in a lava flow) 

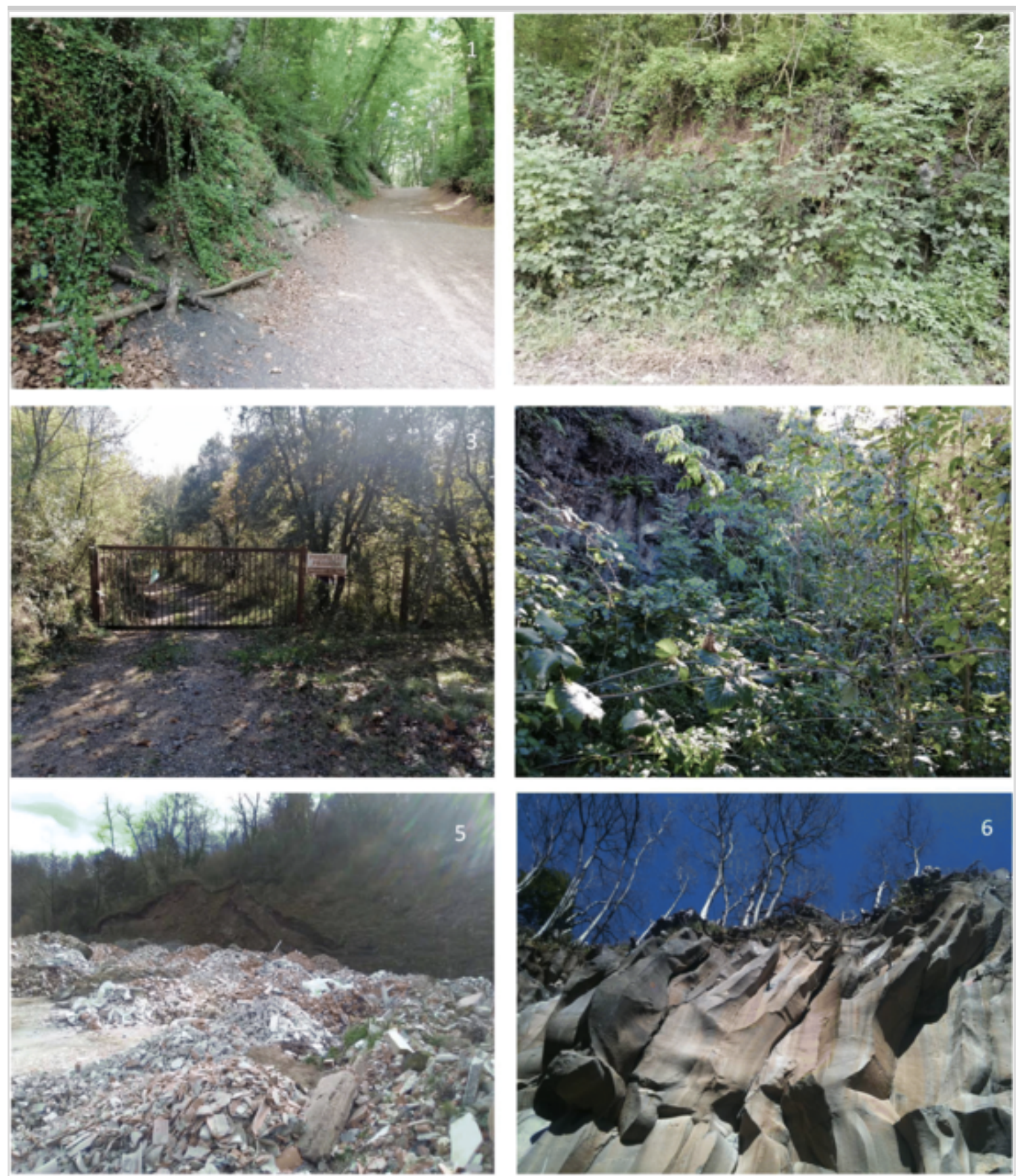

These selected outcrops (Fig. 6) represent the main aspects of the volcanic activity that has characterised the evolution of La Garrotxa Volcanic Field. However, other outcrops that were potentially the most informative for visitors and other aspects such as state of preservation, facility of access, future management and their landownership were also taken into account.

These 12 outcrops were then subdivided into two groups according to their interest in terms of (i) conservation and (ii) dissemination and public use. In the former group aspects such as the state of conservation; potential for restoration; the rarity and exceptionality of its scientific features, whether 
or not it was a typical locality for geological description; its potential from a pedagogical point of view and its spectacularity and beauty were evaluated. In the latter group, the aspects to be considered were the potential for dissemination and use for tourism, their pedagogical value and potential for developing scientific activities, as well as how ease was access and observation, the type of landownership of the outcrop, and the fragility of both the natural and social environment (Table 2).

\section{Table 2}

Criteria for selecting the main outcrops

\section{Conservation}

A) Conservation state

3 Well conserved or easily restorable

2 Poorly conserved and difficult to restore

1 Poorly conserved and impossible to restore

B) Abundance/uniqueness

3 The only outcrop of this type in the natural park

2 Two other outcrops of this type exist in the natural park

1 More than five other outcrops of this

type exist

C) Useful for illustrating volcanic processes

3 Very useful

2 Moderately useful

1 Of little use

\section{Public use and awareness-raising}

A) Possibility of use for activities (scientific, educational, tourism, recreation)

3 Possible use for three type of activities

2 Two types

1 One type

B) Observation conditions

3 Good

2 Average

1 Poor

C) Accessibility

3 Quick access from main roads for all types of vehicles

2 Access along unsurfaced roads not suitable for all vehicles

1 Far from roads (over $30 \mathrm{~min}$ on foot)

D) Type locality

3 Used to describe a volcanic-related process

2 Used to illustrate a description of a volcanic-related process

3 Not used to illustrate a description of a volcanic-related process

E) Associated with other features of interest

3 Associated with other natural or cultural features of interest

2 Few associations

1 Not associated
D) Private property

3 Outcrop on public property or where landowner is amenable 2 Permission required from landowner

3 Problems with landowner

E) Surroundings

3 Visits do not affect the natural, social o architectural surroundings 2 Visits may slightly affect surroundings

1 Visits will seriously affect surroundings 
Conservation

F) Diversity of elements (mineralogical, geomorphological, dynamism, etc.)

3 More than three other visible elements

2 Two or three other visible elements

1 One visible element

\section{Public use and awareness-raising}

F) Space

3 More than 30 people can access the site at once

2 15-29 people can access the site at once

1 Fewer than 15 people can access the site at once

G) Fragility

3 Visits do not cause any

degradation of the site

2 Visits could cause deterioration of the site

1 Visits could seriously damage the site

6-10 Category 3 Low conservation interest

10-14 Category 2 Moderate conservation interest

15-18 Category 1 High conservation interest
7-12 Not apt for visits or raising awareness

12-17 Potentially apt for visits or raising awareness

18-21 Excellent possibilities for visits or raising awareness

Table 3

Catalogue of outcrop interest and value

\begin{tabular}{|l|l|l|l|l|}
\hline & $\begin{array}{c}\text { Conservation } \\
\text { state }\end{array}$ & Abundance/uniqueness & $\begin{array}{c}\text { Useful for } \\
\text { illustrating } \\
\text { volcanic } \\
\text { processes }\end{array}$ \\
\hline 1 & $\begin{array}{l}\text { CINGLERA } \\
\text { TURONELL }\end{array}$ & 1 & 1 & 2 \\
\hline 2 & $\begin{array}{l}\text { CINGLERA } \\
\text { FLUVIÂ N }\end{array}$ & 2 & 3 & 3 \\
\hline 3 & $\begin{array}{l}\text { CINGLERA } \\
\text { TURONELL, }\end{array}$ & 1 & 1 & 1 \\
\hline 4 & $\begin{array}{l}\text { CINGLERA } \\
\text { CAN GRIDO- } \\
\text { CAL SORDET }\end{array}$ & 2 & 1 & 2 \\
\hline 5 & $\begin{array}{l}\text { CINGLES DE } \\
\text { LA CANOVA }\end{array}$ & 2 & 1 & 1 \\
\hline 6 & MOLI FONDO & 3 & 3 & 3 \\
\hline 7 & BOSCARRO & 3 & 3 & 3 \\
\hline
\end{tabular}




\begin{tabular}{|c|c|c|c|c|}
\hline & & $\begin{array}{c}\text { Conservation } \\
\text { state }\end{array}$ & Abundance/uniqueness & $\begin{array}{c}\text { Useful for } \\
\text { illustrating } \\
\text { volcanic } \\
\text { processes }\end{array}$ \\
\hline 9 & $\begin{array}{l}\text { CINGLE DE } \\
\text { FONTFREDA }\end{array}$ & 3 & 2 & 2 \\
\hline 10 & $\begin{array}{l}\text { TORRENT DEL } \\
\text { SOLER }\end{array}$ & 1 & 1 & 1 \\
\hline 11 & $\begin{array}{l}\text { NOC D'EN } \\
\text { COLS }\end{array}$ & 2 & 1 & 1 \\
\hline 12 & $\begin{array}{l}\text { CINGLE DE } \\
\text { LES COLS }\end{array}$ & 3 & 2 & 3 \\
\hline 13 & LES TRIES & 1 & 1 & 1 \\
\hline 14 & $\begin{array}{l}\text { MOLI DE LA } \\
\text { TORRE }\end{array}$ & 1 & 1 & 1 \\
\hline 15 & $\begin{array}{l}\text { MOLI DE } \\
\text { TIRABURRES }\end{array}$ & 1 & 1 & 1 \\
\hline 16 & $\begin{array}{l}\text { VOLCÀ } \\
\text { GARRINADA }\end{array}$ & 3 & 2 & 3 \\
\hline 17 & $\begin{array}{l}\text { VOLCÀ } \\
\text { MONTSACOPA } \\
\text { (Gredera E) }\end{array}$ & 2 & 1 & 2 \\
\hline 18 & $\begin{array}{l}\text { VOLCÀ } \\
\text { MONTSACOPA } \\
\text { (Gredera S-W) }\end{array}$ & 3 & 3 & 3 \\
\hline 19 & $\begin{array}{l}\text { VOLCÀ RACÓ } \\
\text { (Gredera N) }\end{array}$ & 1 & 2 & 2 \\
\hline 20 & $\begin{array}{l}\text { BARRANC DE } \\
\text { GARROFÀS }\end{array}$ & 3 & 3 & 3 \\
\hline 21 & $\begin{array}{l}\text { LA } \\
\text { POMAREDA }\end{array}$ & 3 & 3 & 3 \\
\hline 22 & $\begin{array}{l}\text { GREDERA S } \\
\text { (Costat } \\
\text { Carretera) }\end{array}$ & 2 & 1 & 2 \\
\hline 23 & $\begin{array}{l}\text { VOLCÀ } \\
\text { CROSCAT } \\
\text { (Gred N-W, } \\
\text { abocador) }\end{array}$ & 2 & 1 & 2 \\
\hline
\end{tabular}




\begin{tabular}{|c|c|c|c|c|}
\hline & & $\begin{array}{c}\text { Conservation } \\
\text { state }\end{array}$ & Abundance/uniqueness & $\begin{array}{c}\text { Useful for } \\
\text { illustrating } \\
\text { volcanic } \\
\text { processes }\end{array}$ \\
\hline 24 & $\begin{array}{l}\text { VOLCÀ } \\
\text { CROSCAT } \\
\text { (Gredera N-E, } \\
\text { Tall) }\end{array}$ & 3 & 3 & 3 \\
\hline 25 & $\begin{array}{l}\text { V.PUIG DE } \\
\text { MARTINYÀ } \\
\text { (Gredera N-W) }\end{array}$ & 2 & 1 & 1 \\
\hline 26 & $\begin{array}{l}\text { V.PUIG } \\
\text { SAFONT } \\
(\text { Gredera N-W) }\end{array}$ & 2 & 2 & 1 \\
\hline 27 & $\begin{array}{l}\text { V.PUIG } \\
\text { MARTINYÀ } \\
\text { (Gredera N-E) }\end{array}$ & 2 & 1 & 1 \\
\hline 28 & $\begin{array}{l}\text { V.PUIG DE } \\
\text { MARTINYÀ } \\
\text { (Gredera W) }\end{array}$ & 2 & 1 & 1 \\
\hline 29 & $\begin{array}{l}\text { V.PUIG DE } \\
\text { MARTINYÀ } \\
(\text { Gredera W) }\end{array}$ & 2 & 1 & 1 \\
\hline 30 & $\begin{array}{l}\text { PLA DE LES } \\
\text { FORQUES }\end{array}$ & 2 & 1 & 1 \\
\hline 31 & $\begin{array}{l}\text { TALÚS DE LES } \\
\text { FORQUES }\end{array}$ & 2 & 1 & 1 \\
\hline 32 & $\begin{array}{l}\text { V.SANTA } \\
\text { MARG- Talús } \\
\text { pista vessant } \\
\text { N-E }\end{array}$ & 3 & 3 & 3 \\
\hline 33 & $\begin{array}{l}\text { V.SANTA } \\
\text { MARG- Flanc } \\
\text { cràter N-E }\end{array}$ & 2 & 1 & 2 \\
\hline 34 & $\begin{array}{l}\text { V.SANTA } \\
\text { MARG- Flanc } \\
\text { cràter NW }\end{array}$ & 2 & 1 & 2 \\
\hline 35 & $\begin{array}{l}\text { V.ROCA } \\
\text { NEGRA- } \\
\text { Vessant N-W }\end{array}$ & 3 & 3 & 3 \\
\hline 36 & $\begin{array}{l}\text { RIERA DE } \\
\text { SANT ISCLE I }\end{array}$ & 2 & 3 & 2 \\
\hline 37 & $\begin{array}{l}\text { RIERA DE } \\
\text { SANT ISCLE II }\end{array}$ & 2 & 3 & 2 \\
\hline
\end{tabular}




\begin{tabular}{|c|c|c|c|c|}
\hline & & $\begin{array}{c}\text { Conservation } \\
\text { state }\end{array}$ & Abundance/uniqueness & $\begin{array}{c}\text { Useful for } \\
\text { illustrating } \\
\text { volcanic } \\
\text { processes }\end{array}$ \\
\hline 38 & $\begin{array}{l}\text { V. TRAITER } \\
\text { (Gredera N-E) }\end{array}$ & 2 & 2 & 2 \\
\hline 39 & $\begin{array}{l}\text { BARRANC DE } \\
\text { MATABOUS }\end{array}$ & 3 & 2 & 1 \\
\hline 40 & V.CAN TIA & 3 & 3 & 3 \\
\hline 41 & $\begin{array}{l}\text { CAN } \\
\text { BARRANC del } \\
\text { Corb }\end{array}$ & 2 & 3 & 3 \\
\hline 42 & V. CAN SIMÒ & 3 & 2 & 2 \\
\hline 43 & $\begin{array}{l}\text { SALT DEL } \\
\text { CLOT }\end{array}$ & 2 & 1 & 2 \\
\hline 44 & $\begin{array}{l}\text { VALL DELS } \\
\text { ARCS }\end{array}$ & 2 & 1 & 2 \\
\hline 45 & $\begin{array}{l}\text { CINGLE DE } \\
\text { CAN } \\
\text { FORMIGA }\end{array}$ & 2 & 1 & 1 \\
\hline 46 & RIU SER & 2 & 1 & 2 \\
\hline 47 & $\begin{array}{l}\text { TORRENT DE } \\
\text { SANT MARTI }\end{array}$ & 3 & 2 & 1 \\
\hline 48 & TORRENTMAL & 3 & 3 & 2 \\
\hline 49 & $\begin{array}{l}\text { EL CARRER } \\
\text { (Riera dels } \\
\text { Arcs) }\end{array}$ & 3 & 3 & 3 \\
\hline 50 & $\begin{array}{l}\text { CAN } \\
\text { BARRANC }\end{array}$ & 2 & 3 & 3 \\
\hline 51 & $\begin{array}{l}\text { PEDRERA } \\
\text { TURONELL }\end{array}$ & 3 & 2 & 1 \\
\hline 52 & $\begin{array}{l}\text { CINGLERA } \\
\text { TURONELL III }\end{array}$ & 2 & 3 & 3 \\
\hline 53 & $\begin{array}{l}\text { CAN } \\
\text { BARRANC DE } \\
\text { BATET }\end{array}$ & 3 & 2 & 2 \\
\hline 54 & $\begin{array}{l}\text { GREDERA } \\
\text { DEL PUIG } \\
\text { JORDÀ }\end{array}$ & 2 & 1 & 2 \\
\hline
\end{tabular}




\begin{tabular}{|c|c|c|c|c|}
\hline & & $\begin{array}{c}\text { Conservation } \\
\text { state }\end{array}$ & Abundance/uniqueness & $\begin{array}{c}\text { Useful for } \\
\text { illustrating } \\
\text { volcanic } \\
\text { processes }\end{array}$ \\
\hline 55 & $\begin{array}{l}\text { CINGLERA DE } \\
\text { CAN } \\
\text { XERBANDA }\end{array}$ & 2 & 1 & 2 \\
\hline 56 & $\begin{array}{l}\text { CARRETERA } \\
\text { DE COLLTORT }\end{array}$ & 2 & 1 & 1 \\
\hline 57 & $\begin{array}{l}\text { GREDERA } \\
\text { SANT MARC }\end{array}$ & 2 & 1 & 2 \\
\hline 58 & $\begin{array}{l}\text { PEDRERA } \\
\text { PUIG ROIG }\end{array}$ & 3 & 2 & 2 \\
\hline 59 & $\begin{array}{l}\text { TRAVERTINS } \\
\text { LA TORRE I }\end{array}$ & 3 & 2 & 1 \\
\hline 60 & $\begin{array}{l}\text { TRAVERTINS } \\
\text { LA TORRE II }\end{array}$ & 3 & 2 & 1 \\
\hline
\end{tabular}

Table 4.

The 12 outcrops (Fig. 7) that encompass a full spectrum of the eruptive activities occurring in the Catalan Volcanic Field and illustrate a very complete range of the deposits found in typical basaltic volcanic fields.

\begin{tabular}{|l|l|l|l|}
\hline \multicolumn{1}{|c|}{ Name } & $\begin{array}{c}\text { Location } \\
\text { UTM31N } \\
\text { ETRS89 }\end{array}$ & \multicolumn{1}{|c|}{ Exposed deposits } & $\begin{array}{l}\text { Number of } \\
\text { visitors }\end{array}$ \\
\hline $\begin{array}{l}\text { Cliffs at } \\
\text { Castellfollit de la } \\
\text { Roca }\end{array}$ & $\begin{array}{l}\text { X } 461812 \\
\text { Y } 4667201\end{array}$ & Lava flow and columns & $\begin{array}{l}\text { More than } \\
10,000\end{array}$ \\
\hline $\begin{array}{l}\text { El Boscarró former } \\
\text { quarry }\end{array}$ & $\begin{array}{l}\text { X4 59608 } \\
\text { Y 4673798 }\end{array}$ & $\begin{array}{l}\text { Lava flow and columns, } \\
\text { and lenticulars forms }\end{array}$ & $\begin{array}{l}\text { More than } \\
10,000\end{array}$ \\
\hline $\begin{array}{l}\text { Molí Fondo } \\
\text { X } 459551 \\
\text { Y } 4673674\end{array}$ & $\begin{array}{l}\text { Three lava flows, blisters, } \\
\text { columns and lenticular } \\
\text { forms }\end{array}$ & $\begin{array}{l}\text { More than } \\
10,000\end{array}$ \\
\hline $\begin{array}{l}\text { Former quarry at } \\
\text { Can Barranc on El } \\
\text { Cairat }\end{array}$ & $\begin{array}{l}\text { X } 460809 \\
\text { Y } 4673538\end{array}$ & Phreatomagmatic fall & $\begin{array}{l}\text { Less than } \\
100\end{array}$ \\
\hline $\begin{array}{l}\text { Former quarry on } \\
\text { El Montsacopa }\end{array}$ & $\begin{array}{l}\text { X } 457706 \\
\text { Y } 4670571\end{array}$ & $\begin{array}{l}\text { Phreatomagmatic PDC } \\
\text { with volcanic lithics }\end{array}$ & $\begin{array}{l}\text { More than } \\
10,000\end{array}$ \\
\hline
\end{tabular}




\begin{tabular}{|c|c|c|c|}
\hline Name & $\begin{array}{c}\text { Location } \\
\text { UTM31N - } \\
\text { ETRS89 }\end{array}$ & Exposed deposits & $\begin{array}{l}\text { Number of } \\
\text { visitors }\end{array}$ \\
\hline La Pomareda & $\begin{array}{l}\text { X } 461203 \\
\text { Y } 4667462\end{array}$ & Spatter & $\begin{array}{l}\text { Between } \\
1000 \text { and } \\
10,000\end{array}$ \\
\hline $\begin{array}{l}\text { Former quarry NE } \\
\text { of El Croscat }\end{array}$ & $\begin{array}{l}\text { X } 461824 \\
\text { Y } 4667203\end{array}$ & Strombolian fall deposits & 50,000 \\
\hline Track to El Cros & $\begin{array}{l}\text { X } 462725 \\
Y 4665701\end{array}$ & $\begin{array}{l}\text { PDC with sedimentary } \\
\text { lithics }\end{array}$ & $\begin{array}{l}\text { Between } \\
1,000 \text { and } \\
10,000\end{array}$ \\
\hline $\begin{array}{l}\text { Former quarry on } \\
\text { Can Tià }\end{array}$ & $\begin{array}{l}\text { X } 462476 \\
\text { Y } 4663391\end{array}$ & Basaltic ignimbrites & $\begin{array}{l}\text { Less than } \\
100\end{array}$ \\
\hline El Carrer & $\begin{array}{l}X 465875 \\
Y 4664562\end{array}$ & Basaltic ignimbrites & $\begin{array}{l}\text { Less than } \\
100\end{array}$ \\
\hline $\begin{array}{l}\text { Torrent de Cal } \\
\text { Bosquet }\end{array}$ & $\begin{array}{l}\text { X } 464132 \\
\text { Y } 4667400\end{array}$ & PDC with volcanic lithics & $\begin{array}{l}\text { Less than } \\
100\end{array}$ \\
\hline $\begin{array}{l}\text { Former quarry on } \\
\text { El Rocanegra }\end{array}$ & $\begin{array}{l}\text { X } 463181 \\
Y 4665613\end{array}$ & Strombolian fall deposits & $\begin{array}{l}\text { Between } \\
1000 \text { and } \\
10,000\end{array}$ \\
\hline
\end{tabular}

What follows are short descriptions summarising the main aspects of each of the 12 selected outcrops that constitute the most important volcanic sites in the PNZVG.

\section{Castellfollit de la Roca Basaltic Cliffs}

Located about $7 \mathrm{~km}$ east of the city of Olot, these basaltic cliffs lie in the extreme north-east of PNZVG, between the rivers Turonell to the south and Fluvià to the north (Fig. 4). These cliffs are an excellent example of effusive activity and consist of two superimposed lava flows, 210,000 and 192,000 years old (Lewis et al. 2000), which have been partially eroded away by the two abovementioned rivers. The cliffs, which rise $50 \mathrm{~m}$ above these rivers and run for 1 kilometre, provide excellent views of the internal structure of a lava flow (Fig. 6a). The main feature of this outcrop is the well-developed columnar jointing that affects the succession of lava flows. Due to the existence of this pervasive network of joints, frost weathering (freezing-thawing) is concentrated along these cracks and eventually leads to the crumbling and fall of the blocks. They are then carried off periodically by the river when in floods, thereby preventing the fallen 
blocks from building up and stabilising at the bottom of the cliff.

The lava flows rest on Eocene sandstones and marls, and Quaternary gravels, and consist of a 40-m thick layer of black and grey basalt. About $9 \mathrm{~m}$ from the top of the volcanic materials, a layer $(0.2-1.5-\mathrm{m}$ thick) of clay and pyroclasts, easily recognisable by the abundant herbaceous vegetation that grows there, divides the escarpment into two discrete parts, each one corresponding to a different lava flow. The lower zone of the lower lava flow has (i) a 5.5-m-thick, well-developed columnar jointing with prisms around $50 \mathrm{~cm}$ in diameter; (ii) an intermediate zone, $3.5-\mathrm{m}$ thick, with lenticular jointing; and (iii) an upper zone, less than 1-m thick, with columnar jointing again but with columns that are only $30 \mathrm{~cm}$ in diameter. The upper lava flow has four different zones; the first three, starting from the base, are each 5-9-m thick and have obvious columnar jointing, while the uppermost zone is about 9-m thick and has welldeveloped spheroidal weathering.

The medieval village of Castellfollit de la Roca was built on top of these lava flows using, above all, rocks and stones from the flows themselves as building materials.

\section{Sant Joan Les Fonts Lava Flows}

In the town of Sant Joan les Fonts, there are two outcrops of interest (Fig. 4). Firstly, El Boscarró provides a vision of the relationship between welldeveloped columnar and lenticular jointing within a lava flow (Fig. 6b). Five layers can be distinguished here: the lowest has columnar jointing with 5- and 6-sided columns, 20-40 cm in diameter, and 2-3-metres high. The second and fourth layers have slab jointing, while between them in the third layer there is massive material with a few cooling cracks. The fifth and final layer, just below the soil level, is far more altered due to its proximity to the surface and has a marked spheroidal structure. North-west from the quarry face, a stream, La Riera de Bianya, flows along the contact zone between the volcanic materials and the reddish Eocene sedimentary materials.

At El Molí Fondo three lava flows are superimposed along the river Fluvià and are all visible and visitable: the oldest dates from 600,000 years ago (Araña et al. 1983), the second (150,000 years ago) exhibits lenticular 
formations and blisters, while the youngest (133,000 years ago) is characterised by a well-formed series of basaltic columns (Fig. 6c).

\section{Quarry at El Cairat}

A good example of a breccia generated by a phreatomagmatic explosion can be found close to the eruptive centre of the volcano El Cairat on the ridge of Serra Molera in the north of the natural park (Fig. 4). El Cairat is a maar-type volcano with a 120-m-diameter crater excavated in the Eocene substrate (Martí and Mallarach 1987; Martí et al. 2011). It is one of the few examples in the studied area that is almost exclusively composed of phreatomagmatic deposits. The pyroclastic deposits that form this volcanic edifice were emplaced preferentially to the north and south of the crater. The observation point is an old quarry located at the base of the northern flank of the volcano. This outcrop has a 20 -m-thick succession of pyroclastic deposits corresponding to lithic-rich explosion breccias and lapilli-sized fallout and pyroclastic surge deposits (Fig. 6d). The main characteristic of this succession of deposits is the presence of abundant lithic clasts from the red sandstone Eocene basement, which range in size from a few centimetres to up to $5 \mathrm{~m}$.

\section{Montsacopa}

This is one of the most representative and best-preserved volcanic cones in the area. Located inside the city of Olot, Montsacopa, is a steep-sided cinder cone, $94 \mathrm{~m}$ in height and topped off with a circular, 120-m-diameter and 12-m-deep crater. On the south-eastern side of this volcano lie a series of Strombolian deposits resulting from the formation of a scoria cone, conformably above which there is a succession of pyroclastic density current (PDC) deposits caused by the interaction of the magma with a shallow aquifer (Fig. 6e). This outcrop reveals one of the most characteristic features of the La Garrotxa volcanism, namely, the cooccurrence of Strombolian and phreatomagmatic phases during a single eruption (Martí et al. 2011).

\section{La Pomareda}

The quarry at La Pomareda (Fig. 4), together with the two following outcrops (quarry at Croscat and the eastern flank of Santa Margarida), forms part of one of the most recent eruptions in the area, which took place 
about 11-13 ka. In fact, La Pomareda, Croscat and Santa Margarida all lie on a $3-\mathrm{km}$-long eruption fissure oriented NW-SW, from where the eruption started at the southern end with a vent-opening phreatomagmatic phase, visible on the southern flank of the Santa Margarida outcrop. Subsequently, the eruption progressed to the central and northern sectors of the fissure extruding basaltic magma and generating massive spatter and occasionally rheomorphic, welded scoria agglomerates, visible at La Pomareda, and terminated in the centre of the fissure with an important cone-building event that formed the volcano of Croscat (Martí et al. 2011).

The outcrop at La Pomareda, located to the north of Croscat, is visible thanks to quarrying and corresponds to local black-to-reddish spatter deposits with welded blocks and bombs, covered subsequently by a layer of lapilli and a lava flow originating from the eruptive vent at Croscat (Fig. 6f). The scoria fragments are mostly flattened and are up to $1 \mathrm{~m}$ in width and, together with the welding, suggest a very proximal outcrop corresponding to the first stages of the purely magmatic eruptive activity along this eruptive fissure (Martí et al. 2011).

\section{Quarry at Croscat}

This quarry is located on the northern side of the volcano (Fig. 4) and was worked from the 1960s until the beginning of the 1990s. The excavations exposed an outcrop of pyroclastic materials, $150 \mathrm{~m}$ in height and $500 \mathrm{~m}$ in width, that today illustrate perfectly the different phases of the formation of a cinder cone generated by a violent Strombolian eruption phase (Di Traglia et al. 2009).

On the right-hand side, the quarrying was executed in great terraced steps to help stabilise the volcanic material. However, the middle and the lefthand side are less stable and landslips are more frequent. The different layers of fallout scoria consist of irregular, highly vesicular juvenile fragments, for the most part lapilli-sized, and are very well exposed in this outcrop (Fig. 6g). At the base of the sequence, several bombs are visible. The materials are mostly dark grey or black, although in the area closest to the centre of the edifice they are reddish and ochre. In the lowest part of the quarry there is a reddish layer of welded scoria, which corresponds to the first episode in the cone-building phase of the volcano and is very similar to that observed at La Pomareda. On top of the Strombolian fallout 
succession, there is a 2-m-thick laminated layer of finer pale-brownish material that corresponds to phreatomagmatic material deposited at the end of the volcano's explosive activity (Martí et al. 2011).

\section{Eastern flank of Santa Margarida}

On the eastern flank of the volcano of Santa Margarida (Fig. 4), crowned by a maar-type crater, there is a visible outcrop of PDC. On top of a silty soil, which corresponds to the pre-volcanic substrate, lies a layer of compacted phreatomagmatic ash followed by massive lithic-rich pyroclastic flow deposits and several well-stratified beds of medium-tocoarse-grained, dilute pyroclastic surge deposits and associated fine-ash deposits forming, in total, a 3-m-thick succession (Fig. 6h). On top of this there is a layer of black juvenile lapilli scoria fragments and fairly rounded reddish-brown lithics (Eocene red sandstones). This fallout scoria and the previous phreatomagmatic deposits correspond to the initial eruption phases from the Santa Margarida vent (Martí et al. 2011). Finally, at the top of the sequence there is a deposit - a fine-grained scoria deposit with no stratification - that closely resembles the previous layer but without any lithics, which corresponds to the airfall deposits originating from Croscat.

\section{Quarry at Can Tia}

Located on the western side of the volcano of Can Tia, this quarry is one of the few examples of basaltic ignimbrites (massive, scoria-rich, dense PDCs deposits) that are visible in this volcanic field (Martí et al. 2017). Can Tià is a maar-type volcano, with a $270-\mathrm{m}$-wide and 20 -m-deep flat-bottomed crater. It is asymmetrical - its lip is higher to the south - and the sequence of materials that built this volcano, observable in the quarry next to Can Tia, consist only of pyroclastic deposits (Fig. 6i). There are four different units from base to top. The lowest unit corresponds to a 10 -cm-thick, internally massive pyroclastic surge deposit, which rests unconformably on a palaeosoil. The second unit consists of a poorly stratified, non-welded, highly vesiculated lapilli scoria deposit, up to 6-m thick, with a few lithic clasts, some of block size. The third unit overlies conformably the previous one and consists of a 1.5-m-thick, thinly laminated, well-sorted, finegrained scoria deposit rich in lithic clasts of red Eocene sandstones of variable size $(<2-30 \mathrm{~cm})$, with an interbedded ash layer in its upper part. The number of lithics increases gradually towards the top of this deposit, 
which is sheared by the emplacement of the uppermost unit. This final unit is a massive dense PDC deposit (basaltic ignimbrite), up to 3-m thick, that contains abundant Eocene lithic clasts and scoria and highly vesiculated lapilli fragments, all contained in a lithic-rich, ash matrix that has been almost completely transformed into clay minerals, zeolites and iron oxides. The sequence of deposits displayed in this outcrop helps visualise the complex eruption dynamics of this monogenetic volcanism, in which magmatic and phreatomagmatic phases often alternated during the same eruption (Martí et al. 2011). This particular outcrop reveals how the explosive activity began with a short phreatomagmatic event, then changed immediately into a magmatic event (second and third units) and then changed back to a phreatomagmatic event (upper part of the third unit and fourth unit) during the course of the eruption.

\section{Riera dels Arcs}

This is another excellent outcrop for observing the full succession of a basaltic ignimbrite deposit (Martí et al. 2017). Located near Mas Carrer in Riera dels Arcs (Fig. 4), this outcrop is about $1.5 \mathrm{~km}$ from the vent of the volcano of Sant Jordi (Fig. 4). Two units are visible (Fig. 6j): the lower unit consists of fine scoria lapilli fall deposits that hug the irregular preexisting topography in the bottom of the gully. It is well-sorted and thinly laminated and mostly composed of highly vesicular, juvenile basaltic scoria clasts. Its total thickness is about $25 \mathrm{~cm}$. The upper unit consists of a brown, massive, 15-m-thick ignimbrite deposit composed of dense-tohighly vesiculated, large lapilli-to-bomb-sized juvenile scoria fragments that are sometimes flattened, together with lithic lapilli and blocks of Eocene sedimentary rocks and previous lavas, all supported by an indurated ash and fine lapilli matrix. The base of the upper unit is mostly planar and corresponds to a fine-grained layer that gradually grades into a lithic-rich horizon, about 0.4-m thick, composed of dense fragments of Eocene sediments and older lavas up to $50 \mathrm{~cm}$ in diameter that are irregularly distributed. In the rest of the deposit, the lithic content varies vertically and forms lithic-rich zones or lenses. Juvenile clasts tend to be concentrated towards the top. The top of the deposit has been partially eroded, reworked and transformed into a palaeosoil.

\section{Torrent de Cal Bosquet}

This outcrop is located to the north-east of the village of Santa Pau (Fig. 4). 
It exhibits a succession of dilute PDC deposits (surges) emplaced during the final explosive episode originating from Croscat (Martí et al. 2011). This outcrop lies atop a former fluvial terrace; its lower part is characterized by a succession of levels of fine lapilli fall deposits, while its upper part, which is clearly differentiated, has grain-supported levels of ash affected by tractive structures and by erosive and/or canaliform morphologies. This outcrop is exceptional due to the visibility of a large number of erosive canaliform strata, with an abundance of Type A dunes (Fisher and Schminke, 1984) that cross at low angles and the presence of anti-dunes. These anti-dunes are eroded by reworked alluvial sediments that correspond to lahars provoked by the rainfall that accompanies this type of eruption.

AQ2

\section{Quarry at Rocanegra}

The quarry on the northern flank of the volcano of Rocanegra, located $1 \mathrm{~km}$ to the west of Santa Pau (Fig. 4), is an excellent site for studying the formation of a cinder cone composed of lapilli scoria and bombs formed during a pure Strombolian magmatic eruption. The outcrop has a wellstratified succession of fallout deposits, dipping in equilibrium with the slope, that corresponds to a small cinder cone (Fig. 61). All the deposits are grain-supported and well classified, with grain size varying from block size to medium-sized lapilli, and all are clasts of vesiculated basaltic scoria. Some bombs are also visible in some layers in this succession. Another interesting characteristic of this particular outcrop, which distinguishes it from the other volcanoes in the area, is the presence of a large number of enclaves of pyroxenite and gabbros, as well as partially melted granitic rocks (Neumann et al. 1999).

\section{Discussion}

In order to preserve and disseminate the volcanological knowledge of an area, it is crucial to carry out a thorough study of its main geological and volcanological values (geodiversity) and accordingly identify its geoheritage and define and undertake appropriate conservation actions. Part of this management must consist of determining which sites are most interesting from a geological standpoint and which are the most suitable for visiting. To complete a full inventory of the outcrops to be protected, a full 
analysis of the conservation status of each site of interest is essential: Is it geologically relevant? Can it be easily observed? Is it on public or private property? Is there good access? Might it become eroded due to over visiting? Thus, using the various proposed criteria (Table 2), it is possible to catalogue the sites of greatest geological interest in the zone that should be conserved and managed as key places for visitors.

In the La Garrtoxa Volcanic Field, over the past two decades, most of the efforts aimed at conserving and describing the region's volcanic heritage have been centred on the outcrops described above. Currently, they are all well conserved and are easily visitable. Taking them as a whole, visitors can obtain a complete picture of the most important volcanic processes that have occurred in this volcanic zone. Each of these selected outcrops is now equipped with information panels in which the main features to be observed are outlined. In addition, these descriptions and detailed indications on how to reach each one, along with a general introduction to volcanism and to La Garrotxa Volcanic Field, are included in a field guide that helps visitors appreciate more fully the geoheritage of the area (Martí et al. 2000). This field guide has become an essential tool for raising awareness of these 12 sites of great geological interest and helps visitors interpret the volcanic features of the natural park through careful observation.

AQ3

The criteria to be considered for preserving the volcanic outcrops like those described here should include the following aspects: (i) the potential loss of sites of geomorphological interest and the difficulties in viewing geological processes due to changes in land use as forests encroach and swallow up pastureland and cropland; (ii) the potential loss of visibility of some outcrops due to landslips and rock falls that occur relatively frequently in this type of volcanic material; (iii) the potential impact caused by overfrequentation-i.e. the erosion of paths, increased noise levels, and the loss of the peace and quiet required for ensuring the quality of visits - that implies the need to regulate public access; and (iv) the potential loss and possible destruction of outcrops and volcanic morphologies such as blisters due to urban growth and the building of new lineal infrastructures such as roads.

Thus, it is essential to take into account the following principles when 
attempting to restore, signpost and promote the protection of this type of geological outcrops: (i) good scientific knowledge of all relevant geological processes; (ii) all restoration work must blend in with the landscape and improve the possibilities of observing the geological processes; (iii) public use (i.e., car-parking, massification and interpretation) must be controlled; (iv) the risk of landslips and rock falls must be minimised; and (v) local bodies including town councils and citizen groups must be involved in all attempts to manage these outcrops.

These sites of geological interest are included in the La Garrotxa Volcanic Zone Natural Park management plan (Pla Especial), which is the main tool for territorial planning used in this protected area. A series of regulations has been established aimed at preserving and protecting the local geological heritage by prohibiting all activities that might either provoke or accelerate erosion and by forbidding any activity that might lead to the degradation and deterioration of the protected area, or hinder the study thereof. This plan bans any excavations or earth movements unless their aim is to improve access to the volcanoes for scientific or educational purposes; permission must always be granted beforehand by the park's management team. As well, the spaces created by past excavations must be kept free of all buildings and all other features that might hamper views of the volcanoes. The plan also states that these sites of exceptional geological interest should be actively managed, that agreements should be sought with landowners to facilitate the management of these volcanic features and that grants can be applied for if and when necessary (Table 4)

The relationship with local town councils and local people living in the park is one of the most interesting indicators of the correct management of these outcrops since in some cases they are co-managed by the Natural Park and local town councils. Of the 12 outcrops classified as 'of great interest', nine are actively managed by the park, of which six are comanaged by the park and local councils (Fig 8). This demonstrates how local authorities and local people are committed to the conservation of the geological heritage of the zone.

\section{Fig. 8}

Photographs before and after the restoration of the outcrop at Molí Fondo (platy and columnas jointing in lava flows) 


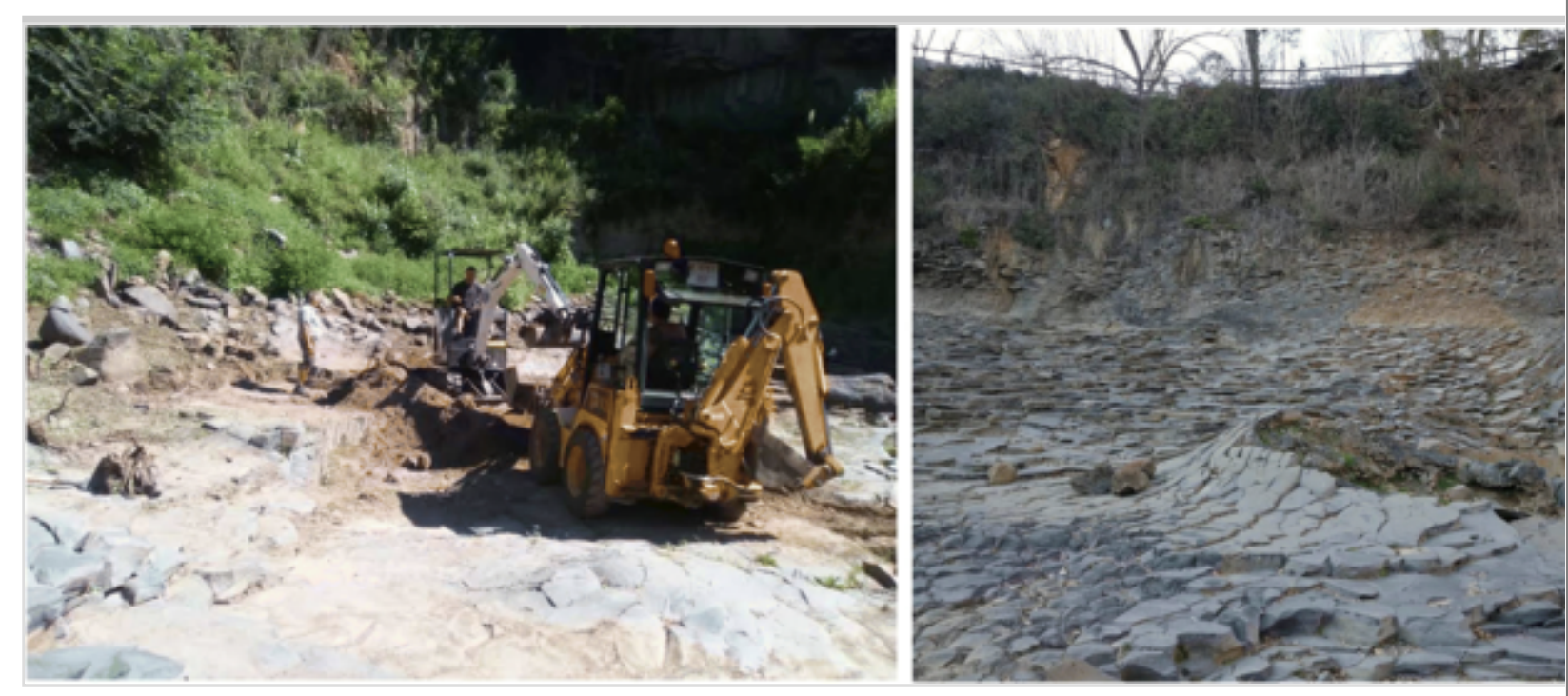

Finally, it is worth mentioning that these selected outcrops are the reference points used for training the Park guides and where they study and learn about local volcanism. This training is important for the correct transmission to visitors of geological and volcanological knowledge and for making them more aware of the need to conserve the geological heritage of this area. This programme has been run since 2000 and to date 400 guides have been trained.

\section{Conclusions}

Sites such as La Garrotxa Volcanic Field harbour a great variety of volcanic features that illustrate a large number of eruptive processes, products and landforms. This makes them very attractive for geotourism and tourism in general, and they are often heavily visited due to their bucolic, easily accessible and gently rolling landscapes and as such are ideal places for raising awareness about the importance of volcanism. However, we should not forget that the volcanic materials present in these areas are often inherently fragile and easy to erode, which means that unchecked public access could lessen their value as heritage sites.

The use of this methodology in La Garrotxa Volcanic Zone Natural Park enabled the most important outcrops in the area to be identified, which crucially, enabled the park to (i) increase the efficiency of actions devoted to conserving the processes that characterize this type of volcanic activity for future generations; (ii) manage public use for those who come to visit the volcanoes; and (iii) ensure that the scientific knowledge of these sites 
provides a service from a ecosystemic and cultural point of view. The correct management of all these aspects will contribute

\section{Acknowledgments}

We would like to thank the staff of the Natural Park for providing the funding, the debates, and the essential information for this study. The English text was reviewed and revised by Michael Lockwood (Walking Catalonia).We thank Jose Luis Macias for his constructive review

\section{References}

\section{AQ4}

Araña V, Aparicio A, Escorza CM, Cacho LG, Ortiz R, Vaquer R et al (1983) El volcanismo neógeno-cuaternario de Catalunya: caracteres estructurales, petrológicos y geodinámicos. Acta Geol Hisp 18(1):1-17 http://revistes.ub.edu/index.php/ActaGeologica/article/view/4294/5298 AQ5

Bolós X, Barde-Cabusson S, Pedrazzi D, Martí J, Casas A, Himi M, Lovera R (2012) Investigation of the inner structure of La Crosa de Sant Dalmai maar (Catalan Volcanic Zone, Spain). J Volcanol Geotherm Res. https://doi.org/10.1016/j.jvolgeores.2012.08.003

Bolós X, Planagumà L, Martí J (2014) Volcanic stratigraphy of the Quaternary La Garrotxa Volcanic Field (north-east Iberian Peninsula). J Quat Sci 29(6):547-560. https://doi.org/10.1002/jqs.2725

Brilha J (2016) Inventory and quantitative assessment of geosites and geodiversity sites: A review. Geoheritage 8:119-134

Brilha J (2018) Geoheritage: inventories and evaluation. In: Reynard E, Brilha J (eds) Geoheritage. Assessment, protection, and management. Elsevier, Amsterdam, pp 69-85

Brocx M, Semeniuk V (2007) Geoheritage and geoconservation history, definition, scope and scale. J R Soc West Aust 90:53-87

Burek CV, Colin DP (2008) The history of geoconservation: an introduction. Geological Society, London, Special Publications 300 (1). 


\section{Geological Society of London: 1-5}

Carcavilla L, Durán JJ, López-Martínez J (2008) Geodiversidad: concepto y relación con el patrimonio geológico Geodiversity: concept and relationship with geological heritage. Geo-Temas 10(1998):1299-1303 http://aguas.igme.es/patrimonio/descargas /concepto_Geodiversidad.pdf

Cas R, Wright J (1988) Volcanic Successions Modern and Ancient. (Springer, Ed.). https://doi.org/10.1007/978-94-009-3167-1

Casadevall TJ, Tormey D, Van Sistine D (2019) Protecting our global volcanic estate: review of international conservation efforts. International Journal of Geoheritage and Parks 7:182-191 AQ6

Cebría JM, López-Ruiz J, Doblas M, Oyarzun R, Hertogen J, Benito R (2000) Geochemistry of the Quaternary alkali basalts of Garrotxa (NE Volcanic Province, Spain): a case of double enrichment of the mantle lithosphere. J Volcanol Geotherm Res 102(3-4):217-235. https://doi.org /10.1016/S0377-0273(00)00189-X

Crofts R, Gordon JE (2015) Geoconservation in protected areas. In: Worboys GL, Lockwood M, Kothari A, Feary S, Pulsford I (eds) Protected area Governance and management. ANU Press, Canberra, pp $531-568$

Di Traglia F, Cimarelli C, de Rita D, Gimeno Torrente D (2009) Changing eruptive styles in basaltic explosive volcanism: examples from croscat complex scoria cone, Garrotxa Volcanic Field (NE Iberian Peninsula). J Volcanol Geotherm Res 180(2-4):89-109. https://doi.org /10.1016/j.jvolgeores.2008.10.020

Gordon JE, Crofts R, Díaz-Martínez E, Woo KS (2018) Enhancing the role of geoconservation in protected area management and nature conservation. Geoheritage 10:191-203

Gray M (2011) Other nature: Geodiversity and geosystem services. Environ Conserv. https://doi.org/10.1017/S0376892911000117 
Gray M (2013) Geodiversity: valuing and conserving abiotic nature, 2nd edn. Wiley Blackwell, Chichester

Gray M (2019) Geodiversity, geoheritage and geoconservation for society. International Journal of Geoheritage and Parks 7:226-236

Lewis CJ, Vergés J, Marzo M (2000) High mountains in a zone of extended crust: insights into the Neogene-Quaternary topographic development of northeastern Iberia. Tectonics 19(1):86-102. https://doi.org/10.1029/1999TC900056

Losantos M, Planaguma L, Pijuan J, de Paz A, Bassols E, Puig C (2000) The geological chart of the Volcanic Zone of la Garrotxa Natural Park. Oral presentation $1: 14-18$

Martí J, Mallarach JM (1987) Erupciones hidromagmáticas en el volcanismo cuaternario de Olot (Girona). Estud Geol 43(1-2):31-40

Martí J, Mitjavila J, Roca E, Aparicio A (1992) Cenozoic Magmatism of the Valencia trough western Mediterranean: relationships between structural evolution and volcanism. Tectonophysics 203:145-165. https://doi.org/10.3989/egeol.87431-2568

Martí J, Planagumà L, Geyer A, Canal E, Pedrazzi D (2011) Complex interaction between Strombolian and phreatomagmatic eruptions in the Quaternary monogenetic volcanism of the Catalan Volcanic Zone (NE of Spain). J Volcanol Geotherm Res 201(1-4):178-193. https://doi.org /10.1016/j.jvolgeores.2010.12.009

Martí J, Planagumà L 1, Geyer A, Aguirre-Díaz G, Pedrazzi D, Bolós X (2017) Basaltic ignimbrites in monogenetic volcanism: the example of La Garrotxa volcanic field. Bull Volcanol. https://doi.org/10.1007 /s00445-017-1113-0

Németh K, Casadevall T, Moufti MR, Marti J (2017) Volcanic Geoheritage. Geoheritage 9(3):251-254. https://doi.org/10.1007 /s12371-017-0257-9

Neumann ER, Martí J, Mitjavila J, Wulff-Pedersen E (1999) Origin and 
implications of mafic xenoliths associated with Cenozoic extensionrelated volcanism in the València Trough, NE Spain. Mineral Petrol. https://doi.org/10.1007/BF01161579

Oliver X (2016) Habitats of La Garrotxa. In: J. Marti \& L. Planagumà (Eds.), La Garrotxa Volcanic Field of Northeast Spain. Geoheritage, Geoparks and Geotourism (Springer). https://doi.org/10.1007 /978-3-319-42080-6_3

Pedrazzi D, Bolós X, Martí J (2014) Phreatomagmatic volcanism in complex hydrogeological environments: La crosa de sant dalmai maar (Catalan Volcanic Zone, NE Spain). Geosphere. https://doi.org/10.1130 /GES00959.1

Planagumà L (2017) Management Plan. La Garrotxa Volcanic Field of Northeast Spain. Geoheritage, Geoparks and Geotourism (Conservation and Management Series. Springer), 121-134. https://doi.org/10.1007 /978-3-319-42080-6

Sharples C (1993) A methodology for the identification of significant landforms and geological sites for geoconservation purposes. Forestry Commission Tasmania

Zwolinski Z, Najwer A, Giardino M (2018) Methods for assessing geodiversity. Geoheritage. Elsevier, https://doi.org/10.1016 /B978-0-12-809531-7.00002-2 